\title{
External fruit morphology of southern African Arundineae (Arundinoideae: Poaceae)
}

\author{
N.P. BARKER* \\ Keywords: achene. Arundincac, Arundinoideac, caryopsis, embryo, external morphology, hilum, Poaceae, surface sculpturing, systematics \\ ABSTRACT \\ Fruits of a number of taxa of all indigenous southern African arundinoid genera were examined by means of SEM. Size, \\ shape, compression, surface seulpturing, embryo and hilum features were recorded and fruits of all genera are illustrated. Results \\ are compared to existing descriptions. The genera are placed in five informal groups according to similarities noted in the fruits.
}

\section{UITTREKSEI.}

\begin{abstract}
Vrugte van 'n aantal taksons van alle inheemse Suider-Afrikaanse arundinoiede genusse is deur middel van aftaselektronmikroskopic ondersork. Groxtte, vorm. samedrukking, oppervlakskulptuur, embrio- en hilumkenmerke is aangeteken en vrugte van alle genusse word geillustreer. Resultate word met hestaande beskrywings vergelyk. Die genusse word volgens coreenkomste wat by die vrugte watargeneem is, in vyf informele groepe geplaas.
\end{abstract}

INTRODUCTION

In his book of grasses of the British 1sles, which is now in its third edition, C.E. Hubbard (1984) included a section on the "seeds" of the grasses, which gave illustrations of the grains of various genera, as well as a key to the genera based mainly on characteristics of their fruits (Hubbard 1984, Ist edn 1954). Despite this emphasis, fruit morphology is still a neglected aspect of grass systematics. In this study, observations on the fruits of the southern African Arundineae are presented.

\section{The tribe Arundineare}

The tribe Arundineae belongs to the subfamily Arundinoideae which Kellogg \& Campbell (1987) consider to be polyphyletic - an assemblage of basal groups and evolutionary dead ends.

The classification by Clayton \& Renvoize (1986), which is followed in this work, provides a broad definition for the tribe Arundineac which encompasses most of the genera in the subfamily. The tribe is a fragmented, heterogeneous group of numerous isolated or weakly linked genera. Other workers divide the subfamily into numerous smaller tribes on the basis of phenetic similarity (Watson 1990) or breeding systems (Conert 1987).

The Arundineac are cosmopolitan. Of the approximately 40 genera in the tribe, 16 occur in southern Africa. Two of these, Arundo L. and Phragmites Adans., are pandemic, and species of a third, Cortaderia Stapf, were introduced into South Africa to control soil erosion on mine tailings dumps (Robinson 1984).

* Botany Department, University of Cape Town, Private Balg, Rondebosch $77(x)$

MS. received: $1992-08-14$

\section{Terminology}

There is as yet no general agreement on the terminology to be used for describing the fruits of the Poaceae. In the Poaceae the ovary is uniloculate. After pollination and fertilisation (ignoring examples of apomixis) the ovule develops into a seed, and the ovary wall becomes a fruit coat or pericarp. In the majority of grasses, the seed and pericarp are fused, forming a grain (Clifford \& Watson 1977). These authors equate this term to the term 'caryopsis' but point out that the grain may take the form of one of a number of different structural types, such as 'achenes', 'nuts' or 'berries'. In the fruit of some grasses, the seed is free from the pericarp. Clayton \& Renvoize (1986) refer to such a fruit as an achene. However, Sendulsky et al. (1987) consider it a modified caryopsis, formed by the collapse of either the endocarp or the endoand mesocarps at a late stage of development, and recommend that use of the term 'achene' in grass biology be discontinued.

In the light of the uncertainty in terminology, the grass grain will be referred to as a fruit in this study. When the necessary distinction between a grain with a free pericarp and a grain with an adnate pericarp has to be made, the term 'achene" will be used for the former, and "caryopsis' for the latter grain type.

\section{The fruit of the Arundineae}

Clayton \& Renvoize (1986) describe the fruit of this tribe as a caryopsis, sometimes with a free or separable pericarp, rarely an achene. They name three genera within the tribe which possess the achene fruit type: Pyrrhanthera Zotov, Dregeochloa Conert and Pentameris P. Beauv. The latter two are endemic to southern Africa and were included in this study.

SEM studies on the fruits of arundinoid genera by Barker (1986, 1989, 1990, 1993, and in prep.), have cov- 


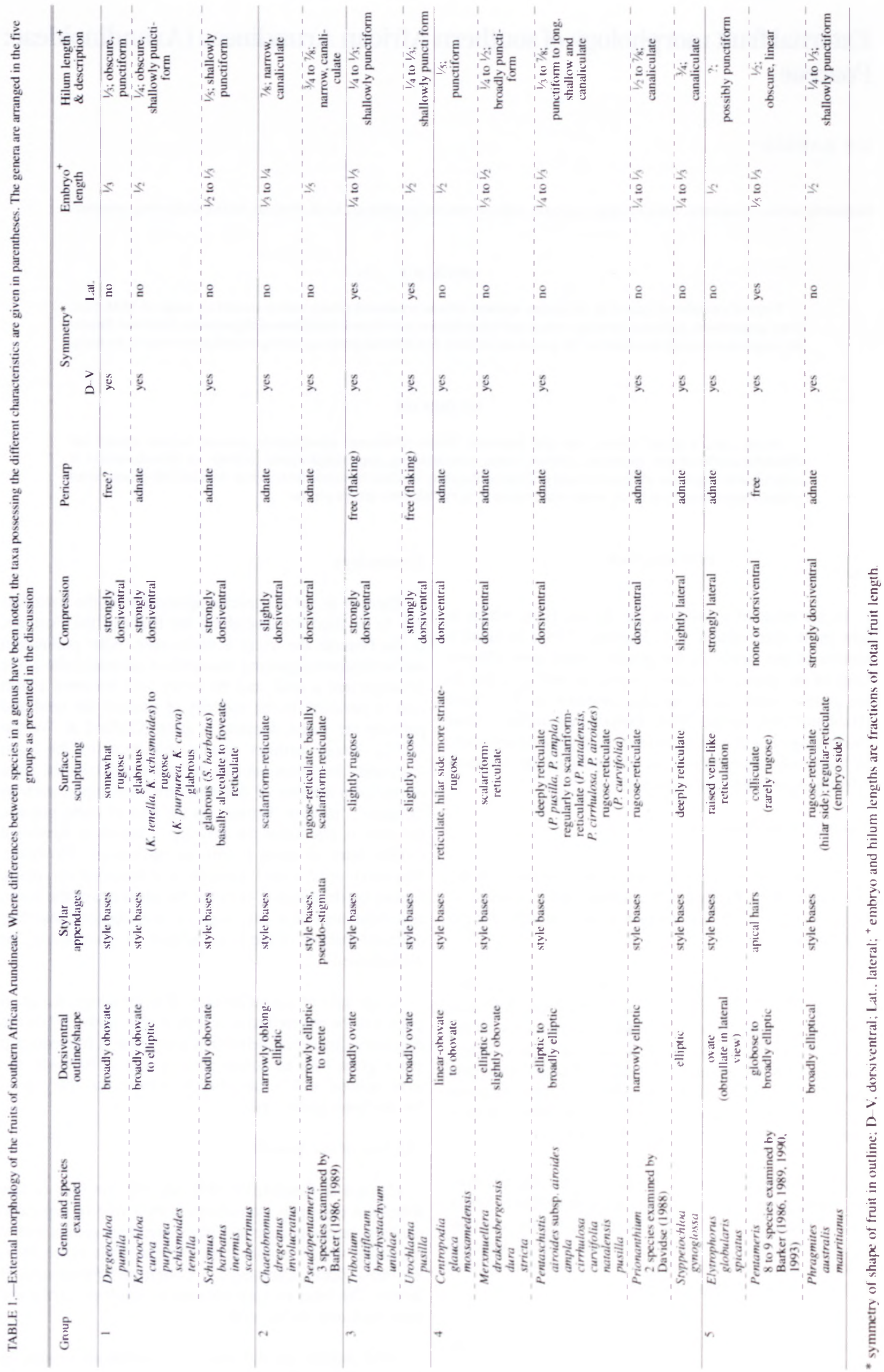


ered fruits of most species of Pentameris P. Beauv. and Pseudopentameris Conert. Davidse (1988) examined the fruits of the genus Prionanthium Desv. These studies are discussed below. In this paper the external morphology of the fruits of the southern African arundinoids is explored.

\section{MATERIAL AND METHODS}

\section{Fruit collection}

Mature fruits of several taxa in each genus were collected from herbarium specimens housed in the National Herbarium in Pretoria (PRE). Taxa representing all endemic southern African genera were sampled, as well as taxa of the pandemic genus Phragmites Adans. Fruits of Arundo L. were unfortunately not available for study. The specimens and species from which fruit were obtained are listed below.

As the fruits were dry, no additional desiccation procedures were followed. Specimens were mounted on the SEM stubs by means of two-sided tape. They were then coated in gold-palladium and examined using an ISI-SX25 Scanning Electron Microscope. Photographs were taken using $60 \times 70 \mathrm{~mm}$ format black and white Ilford FP4 100 ASA film.

\section{Specimens examined}

Centropodia

glauca (Nees) T.A. Cone: De Wimter \& Hardy 8053: Dinter s.n. (= PRE 33115); Mermialler \& Giess 3(681. 32064. mossamedensis (Rendle) T.A. Cope: Boss.s.n. (TM 35977).

Chaelobromus

dregeamus Nees: Merxmialler \& Giess 32059

involucratus (Schrad.) Nees: Boucher 2542.

Dregeochloa pumilla (Nees) Conent: Dinter 6391: Schaeffer 12991.

Elyrophorus

globularis Hack.: Erens 342; Sinith 1847

spicarus (Willd.) A. Camus: Ellis 3718.

Karrocochloa

curva (Nees) Coner \& Türpe: Lichenberg 77/8A.

purpurea (1.f.) Conert \& Türpe: Flamagam /669; (\%. Reid 12.53

schismoides (Stapf ex Conert) Conert \& Tüpe: Hardy 60)7: Munro s.n., Cl. Reid 127I.

tenella (Nees) Conert \& Türpe: Esterhuysen 2.35(K).

Merxmuellera

drakenshergensis (Schwcick.) Conert: Hoener 2184.

dura (Stapf) Conert: Poggenpoel 8274. stricta (Schrad.) Conert: Adanson 3604; Boucher 1837; Kinges 3482.

Pentaschistis

airoides (Nees) Stapf subsp. airoides: 1)avidse 3.3245

ampla (Nees) McClean: Taylor 11054

cirrhulosa (Nees) H.P. Linder: Davidse 3380/.

(arvifolia (Schrad.) Stapt: Davidse $3406 /$.

natalensis Stapf: Braun 279

pusila (Nees) H.P. Linder: Esterhwysen 22763, 24/95.

Phragmites

australis (Cav.) Steud.: Burtt Davy 358; Le Roux 558; Ward 4225.

mauritianus Kunth: Jacobsen 2405; Loeh 489; Miller B/II69.

Schismus

barbatus (Loefl. ex L.) Thell.: Giess 3225; Liebenberg 6651; Verdoorn 1046.

inermis (Stapf) C.E. Hubb.: Lovemore s.n.; Tyson s.n.

scaberrimus Nees: De Winter \& Verdoorn 9037; Oliver, Toelken \& Venter 635; Van Rensburg 12.3.

Styppeiochlon gynoglossa (Gooss.) De Winter: Killick \& Vahrmeijer 3609 .

Tribolium

amplexum Renvoize: Ihlenfeldt 166I.

brachystachyum (Nees) Renvoize: Esterhuysen 1699.

uniolae (L. f.) Renvoize: Kruger KR902; Liebenberg 7719.

Urochlaena pusilla Nees: Davidse 33398, 34021.

\section{OBSERVATIONS AND DISCUSSION}

The salient features of the fruits examined are listed in Table 1, and these features are illustrated in Figures 1-5. Although only a few of the species in the larger genera were examined, the illustrations show that the fruits of different species within a genus are relatively uniform.

The differences at generic level are more distinct, although some genera display strong similarities. These similarities in fruit morphology may be used to form groups of genera on a purely phenetic basis, where character and structural homologies are assumed. Four such groups were assembled on the basis of shared fruit characters. A fifth group comprises three remaining genera, the fruits of which resemble no other genera in the tribe. As the tribe is considered to be polyphyletic, these groups may represent various monophyletic lineages within the Arundineae. These informal groups, and the genera that are placed in each, are discussed below, and the salient features of these groups and genera are presented in Table 2.

TABLE 2.-The groups of genera, their fruit characteristics and the figures illustrating the fruits of each genus

\begin{tabular}{|c|c|c|c|}
\hline Group & Genera & Figures & Fruit characteristics \\
\hline 1 & $\begin{array}{l}\text { Karroochloa } \\
\text { Schismus } \\
\text { Dregeochloa }\end{array}$ & $\begin{array}{l}1 \mathrm{~A}-\mathrm{D} \\
1 \mathrm{E}-\mathrm{H} \\
2 \mathrm{~A}, \mathrm{~B}\end{array}$ & $\begin{array}{l}\text { Broadly obovate, strong dorsiventral compression; surface glabrous to rugose; } \\
\text { embryo } 1 / 3 \text { to } 1 / 2 \text { fruit length; hilum punctiform }\end{array}$ \\
\hline 2 & $\begin{array}{l}\text { Chaetobromus } \\
\text { Pseudopentameris }\end{array}$ & $\begin{array}{l}2 \mathrm{C} \\
2 \mathrm{D}\end{array}$ & $\begin{array}{l}\text { Narrowly oblong-elliptic; surface reticulate; embryo } 1 / 5 \text { to } 1 / 4 \text { fruit length; hilum } \\
\text { canaliculate, } 4 / 5 \text { fruit length }\end{array}$ \\
\hline 3 & $\begin{array}{l}\text { Tribolium } \\
\text { Urochlaena }\end{array}$ & $\begin{array}{l}2 \mathrm{E}-\mathrm{C} \\
2 \mathrm{H}\end{array}$ & $\begin{array}{l}\text { Ovate, strong dorsiventral compression; embryo } 1 / 4 \text { to } 1 / 2 \text { fruit length; pericarp } \\
\text { tlaking }\end{array}$ \\
\hline 4 & $\begin{array}{l}\text { Centropodia } \\
\text { Mexmucllera } \\
\text { Styppeiochloa } \\
\text { Priomanthium } \\
\text { Pentaschisfis }\end{array}$ & $\begin{array}{l}3 \mathrm{~A}, \mathrm{~B} \\
3 \mathrm{C}-\mathrm{E} \\
3 \mathrm{~F}-\mathrm{H} \\
4 \mathrm{~A}-\mathrm{H}\end{array}$ & $\begin{array}{l}\text { Surface reticulate, slight compression in either plane; embryo } 1 / 4 \text { to } 1 / 3 \text { fruit } \\
\text { length; hilum linear. } 1 / 2 \text { fruit length }\end{array}$ \\
\hline 5 & Phragmites & $5 A C$ & $\begin{array}{l}\text { Strong dorsiventral compression; embryo } 1 / 2 \text { fruit length; hilum shallowly } \\
\text { punctiform }\end{array}$ \\
\hline & Pentameris & $5 \mathrm{D}$ & Surface colliculate; pericarp free; apical hairs present \\
\hline & Elytrophorus & SE: $-\mathbf{G}$ & L.atcrally compressed; surface raised-reticulate; embryo $1 / 2$ fruit length \\
\hline
\end{tabular}



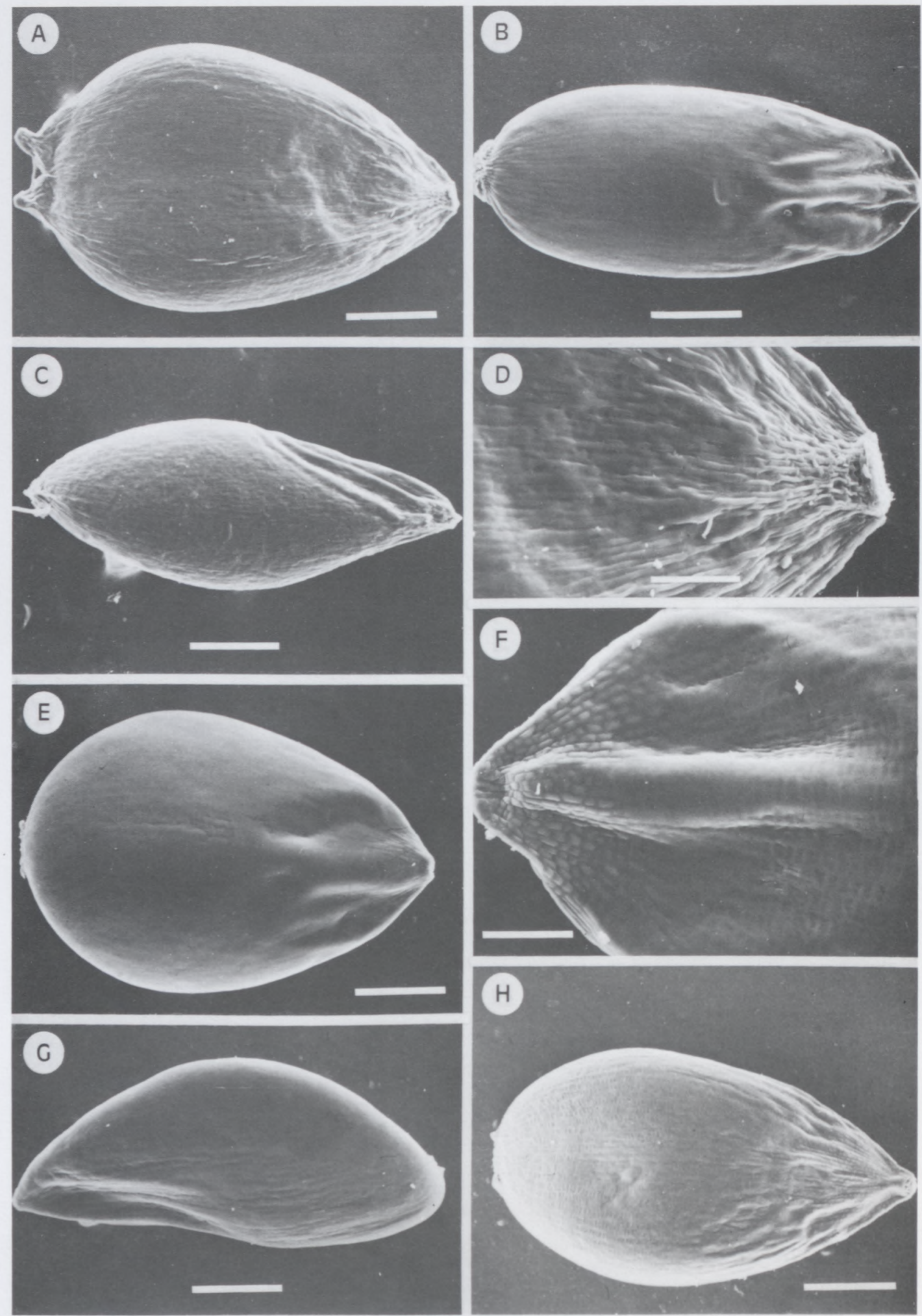

FIGURE 1.-Fruit of Karroochloa and Schismus spp. (Group 1). A, D, K. purpurea: A, hilar side of fruit showing broadly obovate shape and remains of style branches; D, detail of surface features. B, K. schismoides, embryo side. C, K. tenella, lateral view showing degree of compression. E, Schismus scaberrimus, glabrous, broadly obovate, showing large embryo. F, H, S. inermis: F, alveolate surface features; H, hilar side. G, S. barbatus, lateral view, showing asymmetrical outline. Scale bars: A, $220 \mu \mathrm{m} ; \mathrm{B}, 180 \mu \mathrm{m} ; \mathrm{C}, 210 \mu \mathrm{m} ; \mathrm{D}, 80 \mu \mathrm{m} ; \mathrm{E}, 85 \mu \mathrm{m} ; \mathrm{F}, 150 \mu \mathrm{m} ; \mathrm{G}$, $170 \mu \mathrm{m} ; \mathrm{H}, 230 \mu \mathrm{m}$. 


\section{Group 1: Karroochloa, Schismus and Dregeochloa}

Genera in this group share fruits which are broadly obovate, strongly dorsiventrally compressed, generally glabrous or almost so, have embryos $1 / 3$ to $1 / 2$ the fruit length, and punctiform hila.

\section{Karroochloa Conert}

Fruit of all four species of this genus were examined and illustrated in this study (Figure 1A-D). The differences between the fruit of the species examined is slight. but a larger sample size may reveal that these differences intergrade.

Karroochloa was separated from Danthonia DC. on the basis of, among other characters, differences in the fruit (Conert \& Türpe 1969). The latter genus has fruit which are described as having a hilum half to three quarters the length of the fruit and an embryo no longer than a third the length of the fruit. Further differences in the fruit morphology between Karroochloa and Damhonia include the size of the fruit, surface features, and nature of the endospenn (Conert \& Türpe 1969).

Clayton \& Renvoize (1986) include Karroochloa, along with Merxmuellera Conent and several other nonAfrican genera, in Rytidosperma Steud. However, the description of the fruit of Rytidosperma does not match that observed in Karroochloa in this study. Thus the placement of Karroochloa in this genus ought to be questioned, especially in the light of the strong apparent similarities between Karroochloa and Schismus, which is not included in the broad Rytidosperma complex.

\section{Schismus P. Beauv.}

Schismus comprises five species, four of which occur in southem Africa. Fruit of three of the five species were examined (Figure $1 \mathrm{E}-\mathrm{H}$ ). They are all very similar and closely resemble those of Karroochloa. Results presented in Table 1 agree essentially with descriptions provided by Clayton \& Renvoize (1986) and Conert \& Türpe (1974).

\section{Dregeochloa Conert}

Dregeochloa was created by Conert (1966) to accommodate two Danthonia species with an unusual fruit morphology: an obovate caryopsis with a punctiform hilum, and a membranaceous, removable pericarp. As mentioned in the introduction, Clayton \& Renvoize (1986) consider the fruit of this genus to be an achene. The fruits of $D$. pumila were examined (Figure 2A, B). The only other species in the genus, D. calviniensis Conert, is extremely rare.

The pericarp appears to be flaking and casily removable from the fruit (Figure 2A). It is possible that the fruit surface was damaged during manipulations, but the fragility of the pericarp and the apparent ease of removal suggests that it is free from the layers beneath. This and other features recorded in Table I agree with the descriptions by both Conert (1966) and Clayton \& Renvoize (1986). Conert (1966), however, describes the pericarp as membranaceous whereas Clayton \& Renvoize (1986) refer to it as thick.
Dregeochloa is placed in this group on the basis of the shape and compression of the fruit and the large embryo. Conert (1971) observed that the fruit of this taxon is unlike that of any other arundinoid. The somewhat rugose surface and the fact that the fruit appears to be an achene, as noted by Clayton \& Renvoize (1986) and corroborated here, suggests that the relationship of this taxon to the Schismus-Karroochloa alliance is somewhat tentative.

\section{Group 2: Chaetobromus and Pseudopentameris}

The genera in group 2 have narrowly elliptic fruits with reticulate sculpturing, narrow, canaliculate hila extending almost the entire length of the fruit and embryos which are a fifth to a quarter the length of the fruit. These two genera have not been previously considered as closely related.

\section{Chaetobromus Nees}

Chatobromus comprises either two (Barker in Gibbs Russell et al. 1990), three (Clayton \& Renvoize 1986) or four species (Chippindall 1955). Spies et al. (1990) have suggested that the genus may be a polyploid series, divisible into two phenotypic groups: $C$. dregeanus and $C$. involucratus. Fruits of both these groups were examined and found to be identical (Figure 2C), and corroborate the descriptions of Clayton \& Renvoize (1986).

\section{Pseudopentameris Conert}

Barker $(1986,1989,1990)$ found the fruits of all species to be almost identical, differing only in size. Figure 2I) shows the embryo and surface features of the fruit of this genus. Fruits of this genus are unique in having stigmata- like apical appendages, termed pseudostigmata by Barker (1990, and in prep.). These structures, visible on the apices of the ovary, developing and mature fruit, are readily deciduous, being best observed in mature ovaries and developing fruit. These structures have not been observed in Chachobromus, but no immature fruits of this genus have been examined. The descriptions of the fruit of Pseudopentameris by Clayton \& Renvoize (1986) and Gibbs Russell et al. (1990) agree with details given in Table 1. The decision to transfer Pentameris obtusifolia (Hochst.) Schweick. to Pseudopentameris (Barker in prep.) was made partly on the basis of strong similarities of the fruit characters.

\section{Group 3: Tribolium and Urochlaena}

The fruits of genera in this group are ovate, strongly dorsiventrally compressed, with a flaking pericarp. The embryo is a quarter to half the length of the fruit.

\section{Tribolium Desv.}

This genus comprises either 11 (Gibbs Russell et al. 1990) or nine species (Spies et al. 1992). Clayton \& Renvoize (1986) consider this genus to be an outlier in the Arundineae, with at least superficial similarities to genera in the Eragrostideae.

The fruits of this genus are described by Clayton \& Renvoize (1986) as having a reluctantly separable pericarp. This description agrees with that given by Gibbs 

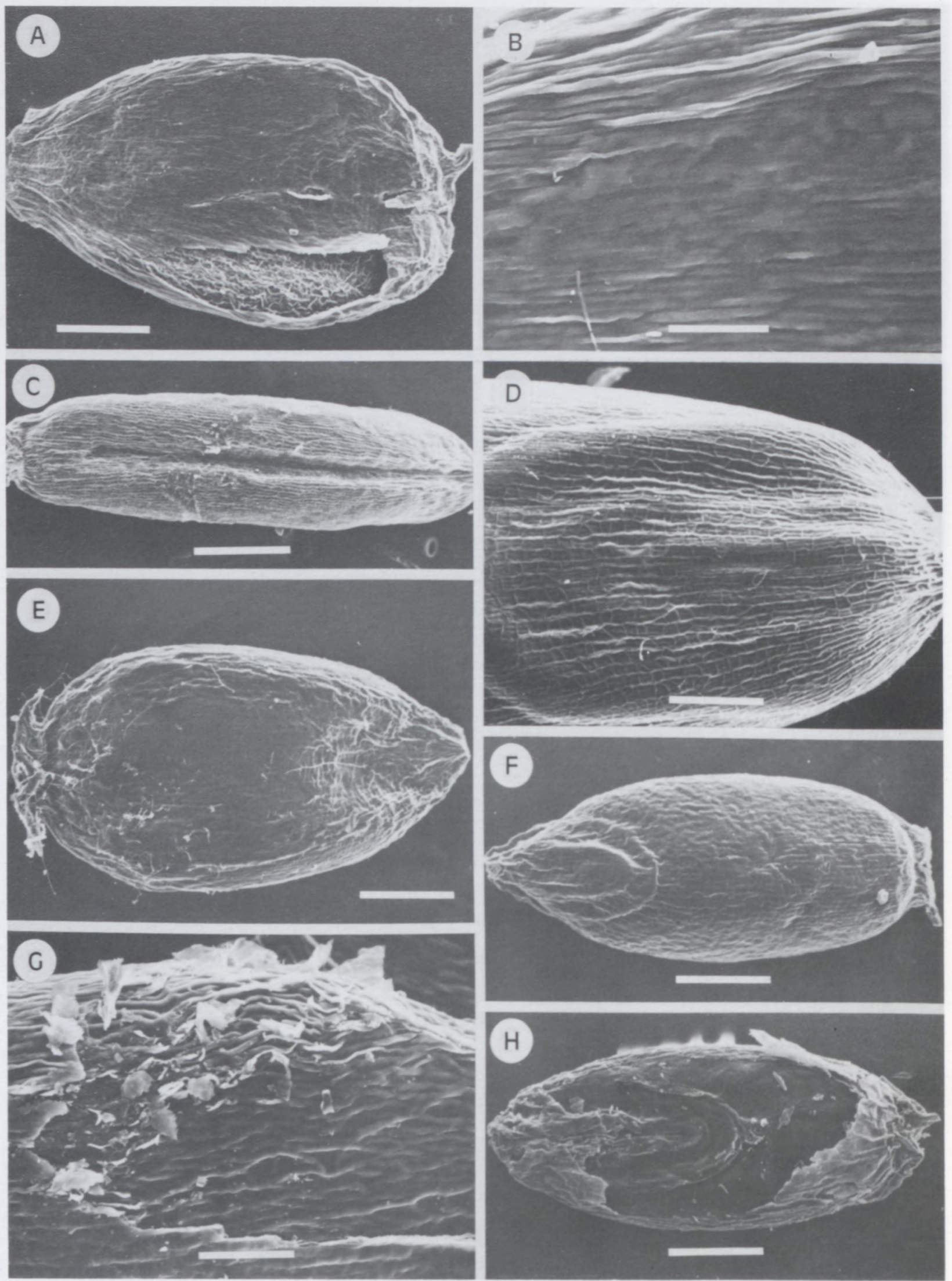

FIGURE 2.-Fruit of various genera in Groups 1, 2 \& 3. A, B. Dregeochloa pumila (Group 1): A, hilar side showing flaking pericarp; B, details of rugose surface. C, Chaetobromus dregeanus (Group 2), hilar side, showing long, canaliculate hilum and scalariform-reticulate surface features; D, Pseudopentameris brachyphylla (Group 2), embryo, showing scalariform-reticulate surface. E-G, Tribolium spp. (Group 3): E, T. uniolae, hilar view, showing rugose surface and stylar remains; F, T. amplexum, embryo side, broadly elliptic in outline; G, $T$. brachystachyum, surface, showing flaking outer layers and rugose surface beneath. H, Urochlaena pusilla (Group 3), showing large embryo and extensive flaking of outer layers. Scale bars: A, $350 \mu \mathrm{m} ; \mathrm{B}, 60 \mu \mathrm{m} ; \mathrm{C}, 560 \mu \mathrm{m} ; \mathrm{D}, 285 \mu \mathrm{m} ; \mathrm{E}, 300 \mu \mathrm{m} ; \mathrm{F}, 425 \mu \mathrm{m} ; \mathrm{G}, 115 \mu \mathrm{m} ; \mathrm{H}, 490$ $\mu \mathrm{m}$. 
Russell et al. (1990), who describe the fruits as being small, with a short hilum and embryo, and a fairly loosely adherent pericarp. These descriptions match observations made in this study, where the fruits of three species in this genus were studied (Figure $2 \mathrm{E}-\mathrm{G}$ ). As shown in Figure $2 \mathrm{G}$, the rugose outer layer of the fruit is separable, matching the decription given by Clayton \& Renvoize (1986). The exposed surface below the pericarp is also rugose.

\section{Urochlaena Nees}

The fruit of the monotypic genus Urochlaena is described by Clayton \& Renvoize (1986) as a caryopsis with a free pericarp, an observation repeated by Gibbs Russell et al. (1990). The embryo is described by these latter authors as being large, while the hilum is short but large. The fruits of Urochlaena (Figure $2 \mathrm{H}$ ) are similar to those of Tribolium.

Tribolitum and Urochlaena thus form a natural group on the basis of all the fruit characters examined. In particular, the nature of the tlaking and separable pericarp indicate a close relationship between the two genera. These observations augment the data from other studies suggesting strong similarities between Urochlaena and Tribolium (Clayton \& Renvoize 1986; Ellis 1988: Spies et al. 1992).

\section{Group 4: Centropodia, Merxmuellera, Styppeiochloa, Prionanthium and Pentaschistis}

The fruits of the genera in this group share features such as a reticulate surface, a hilum approximately half the length of the fruit, an embryo about a quarter to a third the length of the fruit and only slight compression in either plane. However, the genera in this group are probably, at best. only distantly related, given the differences in floral and vegetative morphology.

\section{Centropodia Rchb.}

Two of the four species in this genus were examined. Coner (1962) describes the fruits of Centropodia as being naked caryopses, with linear hila and embryos one third the length of the fruits. This description approximates the observations made in the present study (Figure 3A. B), although Conert's (1962) description of the hilum as being linear differs from the present study where it is shown to be shallowly punctiform (Figure 3B).

In view of the differences in photosynthetic pathways and thus leaf anatomy (Ellis 1984), the relationship of Centropodia to the other genera in this group should be considered as tentative and distant.

\section{Merxmuellera Conert}

At present, 20 species are recognised in this genus. two of which are known only from Madagascar. The fruits of three southern African species of the genus were studied. Each of these species came from a different part of the distribution range of the genus and from a different habitat. The fruits of all three species studied were remarkably similar (Figure $3 \mathrm{C}-\mathrm{E}$ ).
The fruits of Mermmellera have been described as brown, free, almost terete caryopses, two to three millimetres in length (Conert 1970). This description, though sparse, agrees with observations made in this study. Clayton \& Renvoize (1986) include Merxmuellera in Rytidosperma, and their description of the fruits of this latter genus is considered too broad to be applicable to Merxmuellera alone.

\section{Styppeiochloa De Winter}

Styppeiochloa gynoglossa, the only southern African species in the genus, was investigated. De Winter (1966) described the fruits of Styppeiochlor as elliptic caryopses with a linear hilum three quarters the length of the grain and an embryo one quarter the length of the grain, a description matching observations made here. Clayton \& Renvoize (1986) do not provide a description of the fruit. The fruit of $S$. gynoglossa is illustrated in Figure $3 \mathrm{~F}-\mathrm{H}$.

\section{Pentaschistis (Nees) Spach}

Penaschistis is the largest genus in the tribe, comprising 72 species (Linder \& Ellis 1990). The fruits of only six species, including those of $P$. pusilla (= Poagrostis pusilla (Nees) Stapf) were studied. Despite the size of the genus, little variation was found in the external morphology of the fruits investigated (Figure $4 \mathrm{~A}-\mathrm{H}$ ).

The fruits were found to conform with descriptions given by Clayton \& Renvoize (1986) and Gibbs Russell et al. (1990). However, the pericarp description given by the latter workers (free to loosely adherent to fused) was found to be too broad; the pericarp appeared to be fused in all the species studied.

\section{Prionanthium Desv.}

Prionamthium comprises three species. It was revised by Davidse (1988) who described and illustrated the fruit of two species. The genus shares many fruit characters with Pentaschistis, an observation supporting the hypothesis that these two genera are closely related, as proposed by Linder et al. (1990) on the basis of the presence of unusual glands in both these genera. In addition, Davidse (1988) considers the base chromosome number of $x=7$, which is common to both genera, to also be an indication of their close relationship. This is in contrast to Clayton \& Renvoize (1986), who place Prionanthium close to Tribolium and Urochlaena.

\section{Group 5: special cases}

Three genera are placed in this group, not because of any similarities in the nature of the fruit, but simply because their fruits resemble none of the fruits of the other genera discussed above. These 'misfits' are Phragmites, Pentameris and Elytrophoms.

\section{Phragmites Adans.}

Phragmiles is a pandemic genus with two species occurring in southern Africa, P. australis and P. mauritianus. The fruits of these species examined were almost identical. As no detailed description of the fruit from past workers was found, the observations presented here cannot be 

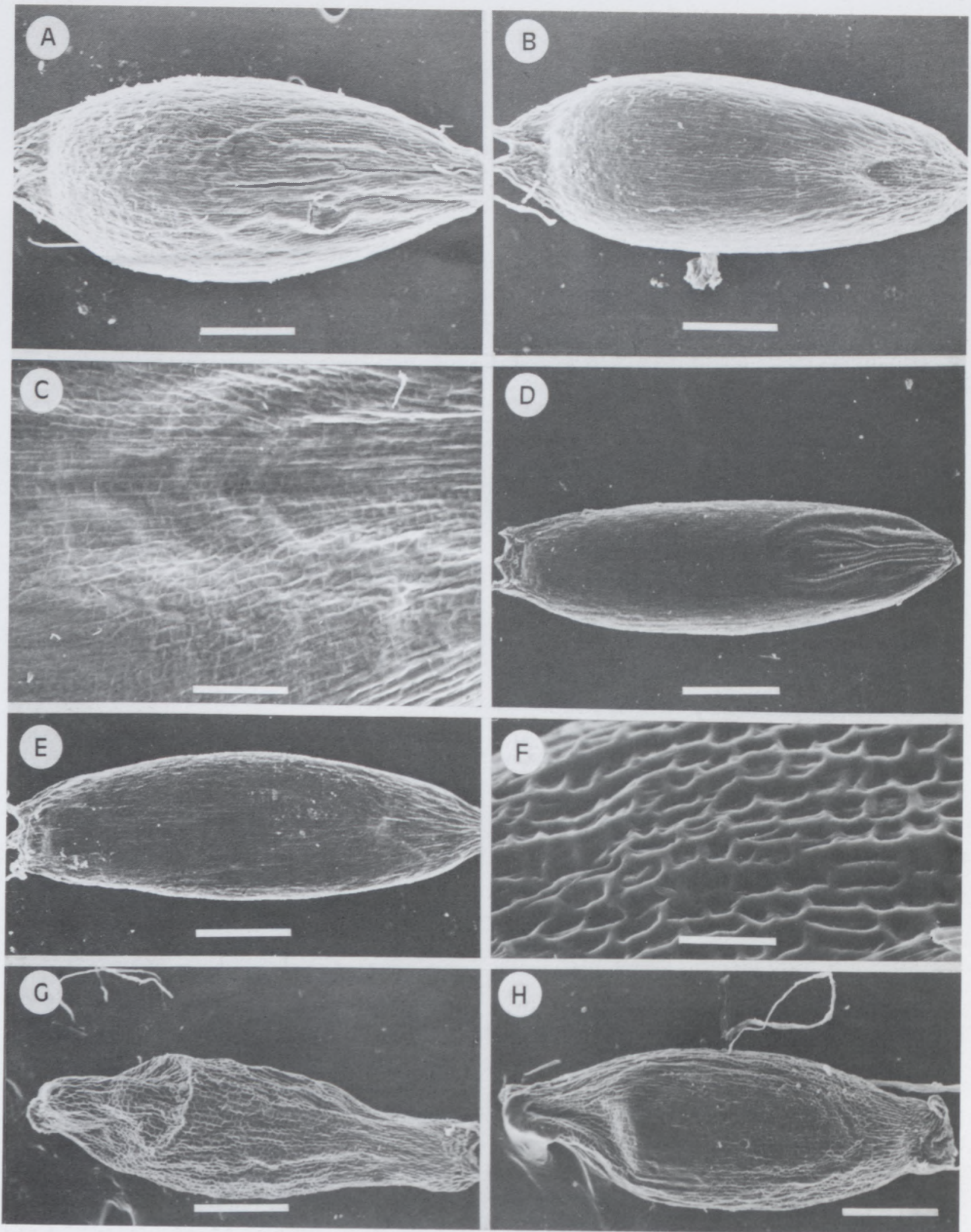

FIGURE 3.-Fruit of genera in Group 4 (Centropodia, Merxmuellera and Styppeiochloa spp). A, B, C. glauca: embryo side, showing large embryo, reticulate surface features and remains of style; B, hilar side, showing punctiform hilum. C, $\boldsymbol{M}$. dura, hilar region, close-up of scalariformreticulate surface features. D, E, M. stricta: D, embryo side, showing embryo a third the length of fruit; E, broad, fairly short hilum and remains of styles. F-H, S. gynoglossa: F, reticulate surface features; G, embryo one third length of fruit; $\mathrm{H}$, lateral view. Scale bars: A, 370 $\mu \mathrm{m} ; \mathrm{B}, 425 \mu \mathrm{m} ; \mathrm{C}, \mathrm{D}, 110 \mu \mathrm{m} ; \mathrm{E}, 695 \mu \mathrm{m} ; \mathrm{F}, 65 \mu \mathrm{m} ; \mathrm{G}, \mathrm{H}, 465 \mu \mathrm{m}$. 

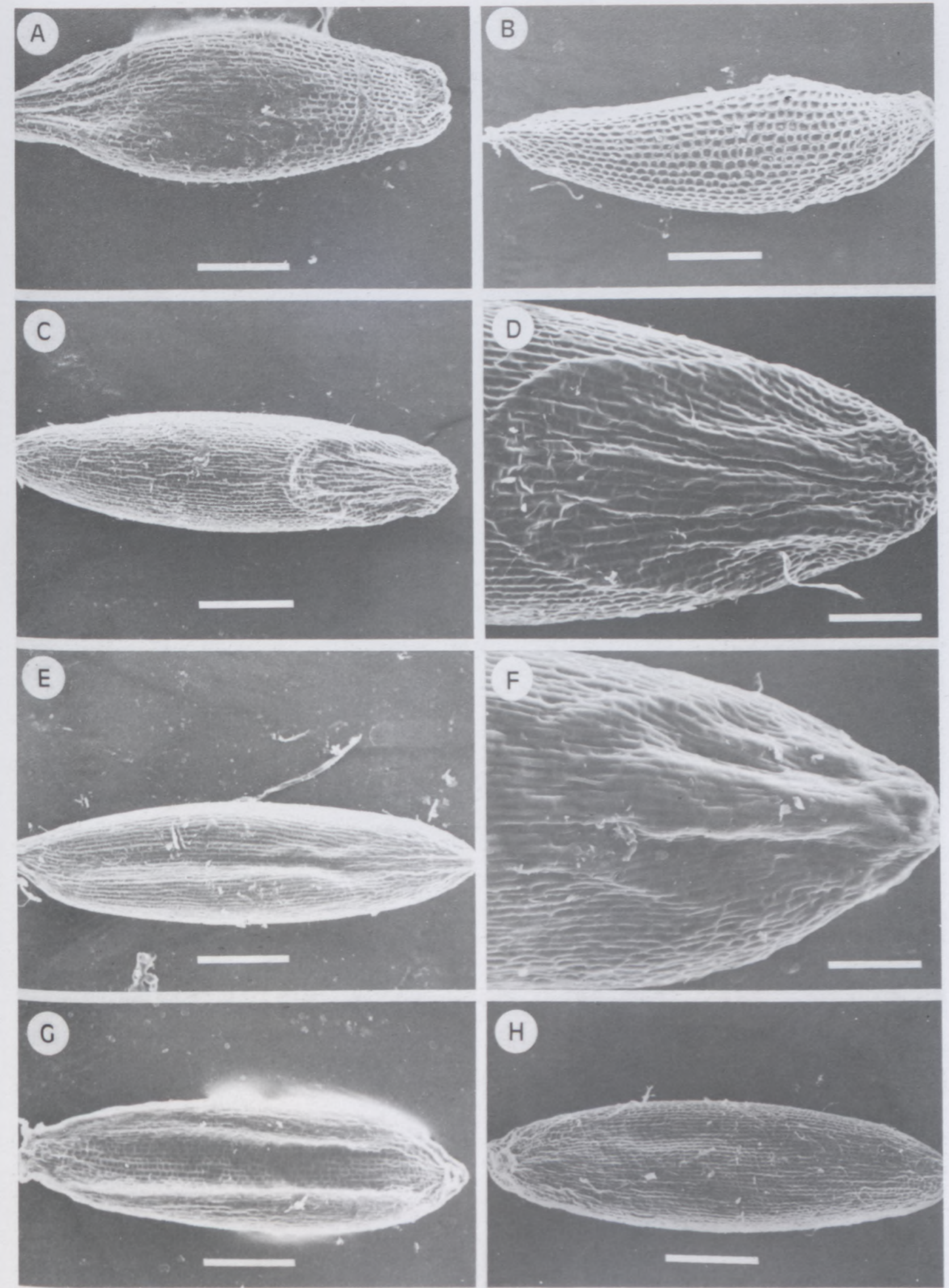

FIGURE 4.-Fruit of Pentaschistis spp. (Group 4). A, P. pusilla, showing embryo and regularly reticulate surface features. B, $P$. ampla, lateral view, with regularly reticulate surface features. C, D, H, P. natalensis: C, embryo side of elliptic fruit: D, embryo region showing reticulate surface features; H, hilar side. E, P. cirrhulosa, showing long, canaliculate hilum. F, G, P. airoides subsp. airoides. F, embryo showing rugose-reticulate surface features; G, deep, broad long hilum. Scale bars: A, $350 \mu \mathrm{m} ; \mathrm{B}, 415 \mu \mathrm{m} ; \mathrm{C}, 455 \mu \mathrm{m} ; \mathrm{D}, 180 \mu \mathrm{m} ; \mathrm{E}, 325 \mu \mathrm{m} ; \mathrm{F}, 85$ $\mu \mathrm{m} ; \mathrm{G}, 230 \mu \mathrm{m} ; \mathrm{H}, 445 \mu \mathrm{m}$. 
compared to past descriptions. The fruits of this genus are illustrated in Figure $5 \mathrm{~A}-\mathrm{C}$.

The fruits of Phragmites are unusual within the context of the southern African Arundineae. Their small size undoubtedly assists in their dispersal by wind, the fruit being dispersed in situ in the floret. Further examination of the fruits of other reed-like grasses such as Arundo, Hakonechloa Honda and Molinia Schrank may assist in clarifying the relationships between Phragmites and other related reed genera with wind dispersed fruit.

\section{Pentameris P. Beauv.}

The fruits of all except one of the nine species of Pentameris have been investigated and illustrated (Barker $1986,1989,1990,1993)$. The fruit of $P$. oreophila N.P. Barker is illustrated in Figure 5D.
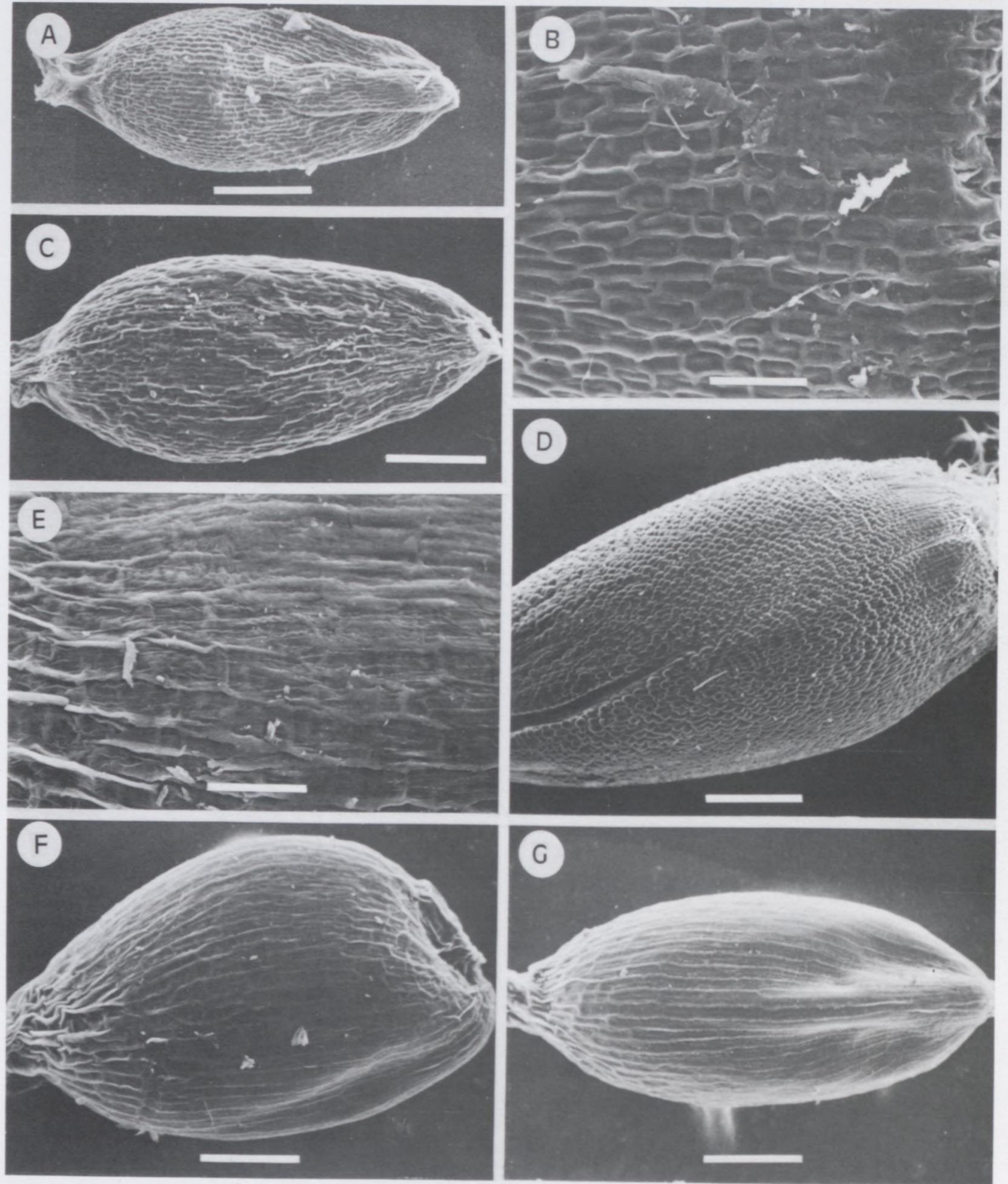

FIGURE 5.-Fruit of genera in Group 5 (Phragmites, Pentameris and Elytrophorus). A, Phragmites australis, showing large embryo, regularly reticulate surface and remains of styles. B, C, Phragmites mauritianus: B, surface features; C, hilar side showing rugose surface features. D, Pentameris oreophila showing colliculate surface. E-G, Elytrophorus globularis: E, surface detail; F, lateral view showing unusual shape and raised, reticulate surface; G, embryo view. Scale bars: A, $380 \mathrm{~mm}$; B, $250 \mathrm{~mm} ; \mathrm{C}, 80 \mathrm{~mm}$; D, 490 mm; E, $280 \mathrm{~mm}$; F, $140 \mathrm{~mm}$; G, 155 mm. 
Pentameris possesses fruits which differ markedly from other southern African arundinoid genera, in both external and internal structure. The fruits of this genus are achenes with apical appendages in the form of hairs or hair-like structures.

These two characters clearly distinguish this genus from the closely related and probable sister genus Pentaschistis. Thus in a phylogenetic system based on overall morphology, Pentameris would belong in group 4. However, on the basis of phenetic groupings employed here, it is treated as an exceptional taxon.

\section{Elytrophorus P. Beauv.}

Elytrophorus differs from the other genera of the Arundineae in having dimorphic spikelets and a membranous ligule (as opposed to the more usual arundinoid ligule comprising a row of hairs).

Both species in this genus were examined, and the fruits of these two taxa were identical in all but size, those of $E$. globularis being far larger than those of $E$. spicatus (Figure 5E-G). Schweickerdt (1942) reported that the embryo is almost as long as the grain, whereas Clayton \& Renvoize (1986) consider the embryo to be only half the length of the fruit, a size more in keeping with that observed here. Schweickerdt (l.c.) alludes to the caryopsis as 'showing the remains of the pericarp', implying that the pericarp is separable. However, Clayton \& Renvoize (1986) do not consider the fruit of this genus to be an achene. Instead, the pericarp is described, somewhat confusingly, as being free.

The shape of the fruit of these species is like that of no other southern African arundinoid, and it is not possible to place it in any of the other groups described above, which only serves to enhance the confusion of this taxon's uncertain affinities: Clayton \& Renvoize (1986) consider Elytrophoras to have uncertain affinities, and Chippindall (1955) placed it in the Eragrosteac.

\section{CONCLUSION}

This study has revealed that the diversity in the floral and vegetative morphologies of the genera of southern African Arundineae is parallelled by an equally diverse set of fruit morphologies. However, this diversity is generally minimal at infrageneric levels. Despite the diversity in fruit morphology, certain genera are united in almost all fruit characters examined (Tribolium and Urochlaena; Karroochloa and Schismus). Where this occurs, it is interpreted as indicating a strong degree of relatedness. Unfortunately, only this very limited phylogenetic interpretation is possible using this data. This is because structural homologies are unproven, only southern African taxa are being examined, and insufficient characters are obtained from a purely SEM-based study. The extension of this study to include non-southern African taxa may, however, provide additional data for comparison.

This study is strictly descriptive. In many instances, the generic relationships proposed on the basis of fruit morphology are speculative. Nonetheless, this study has provided valuable data for incorporation in a phylogenetic analysis which is presently being undertaken in the form of a combined molecular (a survey of chloroplast DNA sequence variation) and morphological survey of the entire tribe. This study has indicated the need for a thorough examination of the nature of the fruit of grasses at the generic level.

\section{ACKNOWLEDGEMENTS}

I would like to thank Mrs A. Romanowski (NBI), Mrs W. Hitcheock (UCT) and Mr R. Carelse (UCT) for assistance with the photographic work, Mrs S. Perold (NBI) for assistance with the SEM. The Curator of the National Herbarium (PRE) is thanked for allowing access to, and SEM exmination of, the specimens cited above. Drs R.P. Ellis, O.A. Leistner and H.P. Linder are thanked for their comments on an earlier draft of the manuscript. This work was carried out while the author was employed by the National Botanical Institute.

\section{REFERENCES}

BARKER. N.P. 1986. The shape and ultrastructure of the caryopsis of Pentameris and Pseudopentameris species (Arundinoideac, Poaceae ). Bothalia 16: 65-69.

BARKER. N.P. 1989. The caryopsis surface of Pentameris and Pseudo pentameris (Arundinoideae, Poaceac) revisited. Bothalia 19 $134-136$.

BARKER. N.P. 1990. The taxonomy of Pentameris $P$ Beaus and Pseudopentameris Comert. M.Sc. thesis, University of the Witwatersiand.

BARKER, N.P. 1993. A biosystematic study of Pentameris (Arundineac, Poaceac). Bothalia 23: 25-47.

BARKER, N.P. in prep. A systematic study of Pseudopentameris (Arundineae; Poaceae).

CHIPPINIDALL. L.K.A. 1955. A guide to the identification of grasses in southem Africa. In D. Meredith, The grasses and pastures of Soluth Africa. Central News Agency, Cape Town.

CLAYTON. W.D. \& RENVOIZE, S.A. 1986. Genera graminum Grasses of the world. Her Majesty's Stationery Office, London.

CI.IFFORD, H.T. \& WATSON, L. 1977. Identifying grasses: data, meth ods and illustrations. University of Queensland Press, St. Lucia.

CONERT, H.J. 1962. Über die Gramineen-Gattung Asthenatherum Nevski. Senckenbergiana Biologica 43:239-266.

CONERT, H.J. 1966. Dregeochloa, eine neue Gattung der Gramineen (Gramineae, Arundinoideae, Danthonieae). Senckenhergiana Biologica 47: 335-343

CONERT, H.J. 1970. Menmuellera: eine neue Gattung der Gramineen (Poaceae: Arundinoideae). Senckenbergiana Biologica 51: 129133

CONERT. H.J. 1971. The genus Danthonia in Africa. Mitteilungen der Botanischen Statssammlung, München 10: 299-308.

CONERT, HJ. 1987. Current concepts in the systematics of the Arundinoideac. In T.R. Soderstrom, K.W. Hilu. C.S. Campbell \& M.E. Barkworth, Grass systematics and evolution. Smithsonian Institution Press. Washington D.C

CONERT, H.J. \& TÜRPE, A.M. 1969. Karroochloa, eine neue Gattung der Gramineen (Poaceae, Arundinoideae, Danthonieae). Senckenbergiana Biologica 5(): 289-318.

CONERT. H.J. \& TÜRPE. A.M. 1974. Revision der Gattung Schismus (Poaceac: Arundinoideac: Danthonicae). Abhandlungen der Senckenbergischen Naturforschenden Gesellschaft 532: 1-81.

DAVIIDSE, G. 1988. A revision of the genus Prionumthium (Poaceac: Arundinoideac). Bothalia 18: 143-153.

DE WINTER. B.I. 1966. Styperiochlod De Winter, gen. nov (Gramineae). Botholia 9: 134-1.37.

ELI.IS, R.P. 1984. Ieaf anatomy of the South African Danthonicac (Poaccac). IX. Asthenatherum glaucum. Bothalia 15: 153-159.

ELLIS, R.P. 1988. Leaf anatomy of the South African Danthonicac (Poaceac). XVI. The genus Urochlaena. Bothalia 18: 101-104.

GIBBS RUSSELL. G.E., WATSON, L., KOEKEMOER, M., SMOOK. L., BARKER, N.P., ANDERSON, H.A. \& DALLWITZ. M.J 1990. Grasses of southem Africa. Memoirs of the Botanical Survey of South Africa No. 58

HUBBARD, C.E. 1984. Grasses. A guide to their structure, identifica tion, uses and distribution in the British Isles. Penguin Books, Harmondsworth, Middlesex, England

KELLOCiG, E.A. \& CAMPBELL. C.S. 1987. Phylogenetic analyses of the Ciramineac. In T.R. Soderstrom, K.W. Hilu, C.S. Campbell \& M.E. Barkworth, Grass systemafics and evolution. Smithsonian Institution Press, Washington D.C.

LINDER, H.P. \& EI.LIS, R.P. 1990). A revision of the genus Pentaschistis (Arundineac: Poaceac). Contributions from the Bolus Herbarium 12. 
LINDER. H.P., THOMPSON, J.F., ELLIS, R.P. \& PEROLD, S.M. 1990. The occurrence, anatomy, and systematic implications of the glands in Pentaschistis and Prionanthium (Poaceae, Arundinoideae, Arundineae). Botanical Gazette 151: 221-233.

ROBINSON, E.R. 1984. Naturalized species of Cortaderia (Poaceae) in southem Africa. South African Joumal of Botany 3: 343-346.

SCHWEICKERDT, H.G. 1942. A taxonomic and anatomical study of Elytrophonus P. Beauv. Annals of the Natal Museum 10: 191-214.

SENDULSKY T, FILGUEIRAS, T.S. \& BURMAN, A.G. 1987. Fruits, embryos and seedlings. In T.R. Soderstrom, K.W. Hilu, C.S.
Campbell \& M.E. Barkworth, Grass systematics and evolution. Smithsonian Institution Press, Washington D. .

SPIES, J.J., DU PLESSIS, H., BARKER. N.P. \& VAN WYK, S.M.C 1990. Cytogenetic studies in the genus Chaetobromus (Poaceae: Arundineae). Genome 33: 646-658.

SPIES, J J DAVIDSE, G \& DU PLESSIS, H. 1992 Cytogenetic studies in the genus Tribolium (Poaceae: Arundineae). American Journal of Botany 79: 689-700.

WATSON, L. 1990. The grass family, Poaceae. In G.P. Chapman, Reproductive versatility of the grasses. Cambridge University Press. 